\title{
СИСТЕМНИЙ АНАЛІЗ МЕТОДІВ ЕВРИСТИЧНОГО НАВЧАННЯ МАТЕМАТИКИ
}

Ротаньова Н. Ю. Системний аналіз методів евристичного навчання математики.

У статті проаналізовано один із важливих компонентів методичної системи - методи навчання математики. Кожний метод навчання описано й розкрито через різноманітність евристичних прийомів, що використовуються під час його реалізації. Серед них особливе місце займають традиційні методи, які доповнені евристичним складником, та спеціальні евристичні методи.

Ключові слова: методи навчання математики, евристичні методи, евристичне навчання математики.

Ротанёва Н. Ю. Системный анализ методов эвристического обучения математики.

В статье проанализировано один из важных компонентов методической системы как методы обучения математики. Каждый метод обучения описан и раскрыт через разнообразие эвристических приемов, которые используются во время его реализации. Среди них особое место занимают традиционные методы, которые дополнены эвристической составляющей, и специальные эвристические методы.

Ключевые слова: методы обучения математики, эвристические методы, эвристическое обучение математике.

Rotanyova N. Yu. System analysis of methods of heuristic training of mathematics.

In the article methods of training of mathematics as one of important components of a methodical system have been examined. Every method of training is described and shown through the variety of heuristic techniques used during its implementation. Among them special place is taken by traditional methods which are complemented by a heuristic component and special heuristic methods.

Key words: methods of training of mathematics, heuristic methods, heuristic training of mathematics.

Сьогодні система навчання математики в Україні орієнтується у своєму розвитку на якісне формування компетентної особистості, яка матиме високий рівень творчого потенціалу та системного мислення. Розв'язання цієї проблеми започатковується в загальноосвітніх та триває у вищих навчальних закладах, і передбачає створення відповідних педагогічних умов. Однією з цих умов є надання навчально-виховному процесу евристичної спрямованості через систематичне використання евристично-орієнтованих систем задач, методів, форм та засобів евристичного навчання. Особливого значення набуває формування евристичної діяльності учнів у навчанні математики. Як відомо, зміст навчання (чому учити) невід'ємний від методів навчання (як учити), тому насамперед, необхідно розглянути один із важливих компонентів методичної системи - методи навчання математики.

Питання вибору ефективних методів навчання досліджували Ю. Бабанский, Є. Голант, І. Лернер, В. Поламарчук, М. Скаткін, А. Столяр, Т. Шамова та ін. Проблемі методів навчання математики, організації евристичної діяльності та іiї управління в навчанні математики, приділяли увагу такі математики та методисти, як: В. Бевз, Г. Бевз , Г. Балк, 
Ю. Колягін, Т. Міракова, Ю. Палант, Г. Саранцев, С. Семенов, О. Скафа, 3. Слєпкань, Л. Фрідман, П. Ериднієв та ін. Однак проблема вибору доцільних методів навчання математики, що сприяють організації евристичної діяльності учнів, залишилась відкритою.

Метою статmі є системний аналіз методів евристичного навчання математики, що сприяють організації пропедевтичної евристичної діяльності учнів 5-6 класів під час вивчення математики.

Методи навчання - це способи діяльності, які використовуються вчителями $i$ учнями в їх сумісній і взаємопов'язаній роботі, спрямованій на досягнення цілей навчання [1]. Кожний метод навчання, як зазначає А. Столяр [9], може бути описаний і розкритий через різноманітність прийомів, що використовуються під час його реалізації. Методи навчання математики повинні спонукати учнів до активної розумової діяльності, прагнення свідомо опанувати змістом дисципліни. Серед них особливе місце займають традиційні методи, за класифікацією І. Лернера і М. Скаткіна [7], де враховуються особливості діяльності учнів і вчителів у процесі навчання:

1) пояснювально-ілюстративний;

2) репродуктивний;

3) проблемний;

4) частково-пошуковий, або евристична бесіда;

5) дослідницький.

Для того щоб ефективно використовувати вибрані методи, вчителю важливо визначитись у тому, коли, у яких випадках і чому краще використовувати один метод, коли інший, як вони узгоджуються 3 конкретною метою навчання, а також із іншими елементами методичної системи (змістом, засобами, організаційними формами навчання). Здійснимо системний аналіз методів навчання математики, що поєднуються 3 метою організації пропедевтичної евристичної діяльності учнів 5-6 класів під час вивчення математики.

Пояснювально-ілюстративний метод полягає в тому, що вчитель повідомляє готову інформацію різними способами, а учні сприймають, усвідомлюють і фіксують їі в пам'яті. До цього методу для учнів 5-6 класу належать розповідь, пояснення, бесіда, робота 3 підручником, демонстрація кінофільмів та ін. Уже на першому етапі засвоєння знань потрібно учити порівнювати нову інформацію з раніше засвоєною, виділяти в ній головне, важливе, аналізувати, що засвідчує вияв деяких евристичних позицій.

Метод передбачає активне залучення в навчальний процес наочності, а це є важливою умовою початкового розвитку евристичного мислення учнів.

Наприклад, до третього уроку за темою «Звичайні дроби» у 5 класі учням можна запропонувати таке.

Склади задачі у малюнках на знаходження дробу від числа і числа за його дробом на усне обчислення.

Склади казку на теми: «Монолог звичайного дробу»; «Магічне перетворення мішаних дробів».

Репродуктивний метод використовується для закріплення на уроці нового матеріалу, перевірки домашнього завдання. Репродуктивний метод навчання забезпечує необхідний мінімум знань і способів дій, а також деяку автоматизацію основних операцій під час вивчення програмного матеріалу, тобто те, що потрібне учням 5-6 класів як основа для оволодівання більш складного матеріалу.

Наприклад, однією 3 головних змістових ліній курсу «Математика» в школі $\epsilon$ функціональна лінія. На етапі вивчення математики у 5-6 класі, графічні уміння і навички, як 
зазначається в програмі [5], вже мають бути сформовані в учнів, бо вони є тим підгрунтям, що забезпечує успішне вивчення цієї змістової лінії у наступних класах алгебри і геометрії, а також інших навчальних предметів, де застосовуються математичні знання. Так, у шостому класі в темі «Раціональні числа та дії над ними» учні ознайомлюються 3 координатною площиною та прикладами графіків залежностей між величинами. Програмою передбачається, що на даному етапі розвитку школярів вони повинні розв'язувати вправи, що передбачають:

- знаходження координати точки на координатній прямій та побудову точки за ії координатою;

- знаходження координат точки на координатній площині та побудову точки за іiі координатами;

- побудову окремих графіків залежностей між величинами за точками;

- аналізує графіки залежностей між величинами (відстань, час; температура, час тощо).

Використовуючи репродуктивний метод учитель зосереджує учнів на вправах, що дозволяють розпізнавати приналежність точок до певних осей координат чи четвертей (рис. 1).

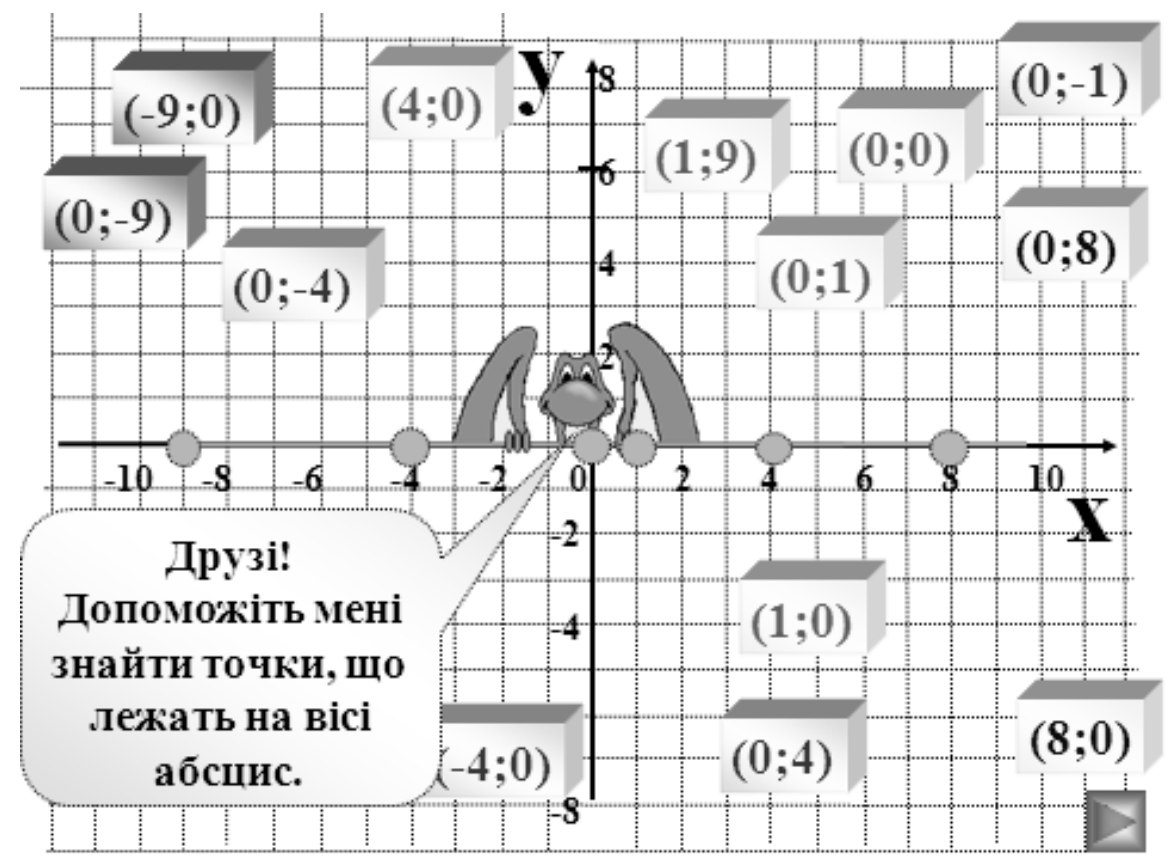

Рис. 1

Наочно це можливо зробити з використанням спеціально розроблених розгалужених презентацій, які вчитель може готувати на урок (про методику розробки таких комп'ютерно орієнтованих уроків йдеться, наприклад, у роботі О.Скафи та О. Павліни [8] та роботі Д. Васильєвої [3]).

Для більш грунтовного сприйняття й усвідомлення цього матеріалу доречно запропонувати евристичні завдання на розпізнавання різноманітних залежностей. Такими завданнями можуть бути, наприклад, різноманітні прислів'я, які учні спочатку разом 3 учителем переводять 3 мови народної мудрості на математичну мову, а потім вже самі знаходять нові приклади.

Під час такої роботи використовуються евристичні прийоми аналізу, зіставлення, порівняння, модифікація та ін. Наприклад: «Як у лісі крикнеш - така й луна буде», «Що посієш - те й пожнеш», «Чим далі в ліс, тим більше дров», «Як ми вбрані - в такій ми й 
шані» - ілюструють пряму пропорційність. «Скільки вовка не годуй, а він у ліс дивиться»сталу функцію у $=$ C.

Так, описані вище два методи є необхідними для організації й управління пропедевтичною евристичною діяльністю учнів, але недостатніми, оскільки мало сприяють розвитку продуктивного мислення, пізнавальній активності й самостійності учнів.

Організація проблемних ситуацій та їх розв'язування є основою методу проблемного навчання [6]. Застосування цього методу у навчанні математики в 5-6 класах посилює увагу учнів, активізує процес сприймання й усвідомлення того, що пояснює вчитель.

Наприклад, використовуючи сюжетні математичні задачі, вчитель для пошуку їх розв'язання висуває певні припущення, які стають для учнів проблемами, що спонукають їх до використання різноманітних евристик у процесі пошуку їх розв'язання. Великі можливості для створення проблемних ситуацій мають творчі завдання щодо складання задач і розв'язання однієї задачі різними способами.

Для залучення учнів до самостійного розв'язування проблем їх необхідно попередньо вчити виконувати окремі кроки розв'язування, етапи дослідження. I тут доречний частковопошуковий метод або евристична бесіда. У курсі математики 5-6 класів частковопошуковий метод навчання використовується лише фрагментарно. Його суть полягає в самостійному розкритті учнями нового змісту при ненав'язливій допомозі вчителя. Цей метод має передбачати активне залучення учнів до пошуку розв'язання поставленої задачі або під керівництвом учителя, або на основі використання евристичних порад, правил орієнтирів, вказівок, евристичних підказок тощо. Процес мислення при цьому набуває продуктивного характеру, він поетапно спрямовується та контролюється або вчителем, або самими учнями.

Наприклад, пропонується завдання: учениия знайшла НСК $(33,198)$ і отримала 99. Не перевіряючи обчислень, учитель визначив, щзо була допущена помилка. Як він изе зробив? Учням надається можливість після закріплення правила знаходження НСК чисел проаналізувати його і знайти відповідь на запитання в задачі.

Евристична бесіда відрізняється від традиційної бесіди тим, що ii успіх застосування забезпечується вмілою системою питань учителя, яка вимагає продуманого складання плану бесіди з можливими відповідями. Важливо, щоб питання стимулювали думку, а не підказували ідею розв'язання. Окрім того, у процесі постановки серії запитань необхідно поступово знижувати рівень проблемності задач, щоб вони були логічно пов'язані, стимулювали як логічні, так й інтуїтивні процедури мислення, сприяли постановці допоміжних задач, кожне нове запитання приводило до нового, несподіваного погляду на задачу. Висока загальна й математична культура, спритність, уміння коротко, просто і ясно ставити запитання, змінювати їх у випадку потреби - такі якості вчителя забезпечують успішне застосування цього методу.

Для керування пропедевтичною евристичною діяльністю учнів необхідний дослідницький метод навчання. Методичною вимогою під час застосування дослідницького методу є побудова таких задач, які б забезпечили творче застосування учнями основних знань (ідей, понять, методів пізнання) у процесі розв'язування доступних їм проблем курсу, оволодіння рисами творчої діяльності, поступове зростання складності розв'язуваних проблем. Завдання вчителя - спонукати учнів самостійно формулювати правила, висновки 3 наступним колективним виправленням недоліків і помилок.

Наприклад, під час вивчення теми «Множення і ділення десяткових дробів» учням можна запропонувати наступне дослідження. 
Досліди на прикладах: у скільки разів збільшується кількість иџифр після коми, якщо число звести у квадрат, у куб.

Такий навчальний процес виховує гнучкість мислення, здатність учня відходити від готових шляхів, від шаблонів у міркуваннях і висновках, тобто більшою мірою сприяє евристичній діяльності.

У навчанні математики, окрім традиційних, використовуваними $є$ i спеціальні евристичні методи [10]. Під час організації пропедевтичної евристичної діяльності їм надається перевага, бо вони більшою мірою ніж інші сприяють формуванню евристичних умінь учнів 5-6 класів, активізації їх евристичної діяльності як на уроках математики, так і в позакласній роботі на евристичному гуртку. Серед них для учнів 5-6 класів найбільш уживаними можуть бути такі:

Метод евристичного спостереження (рис. 2);

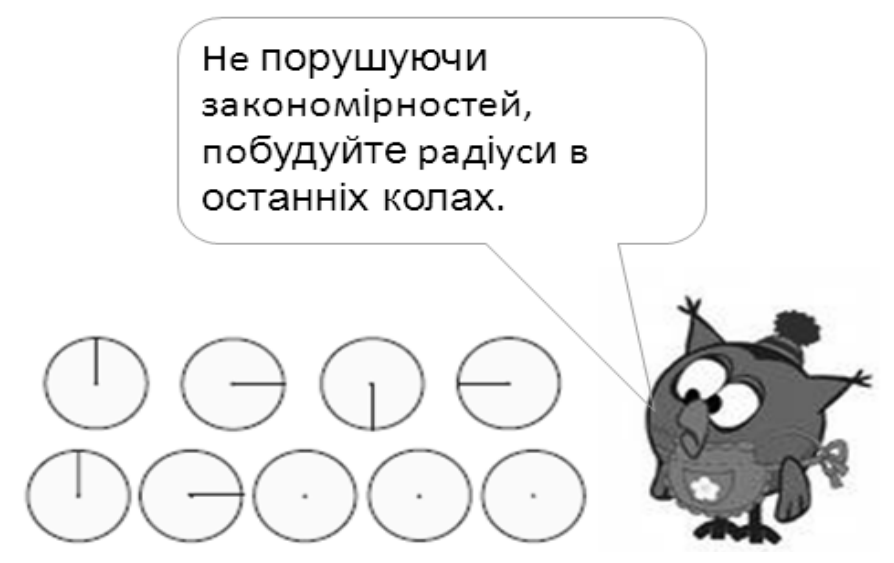

Рис. 2

Метод евристичного дослідження (рис. 3);

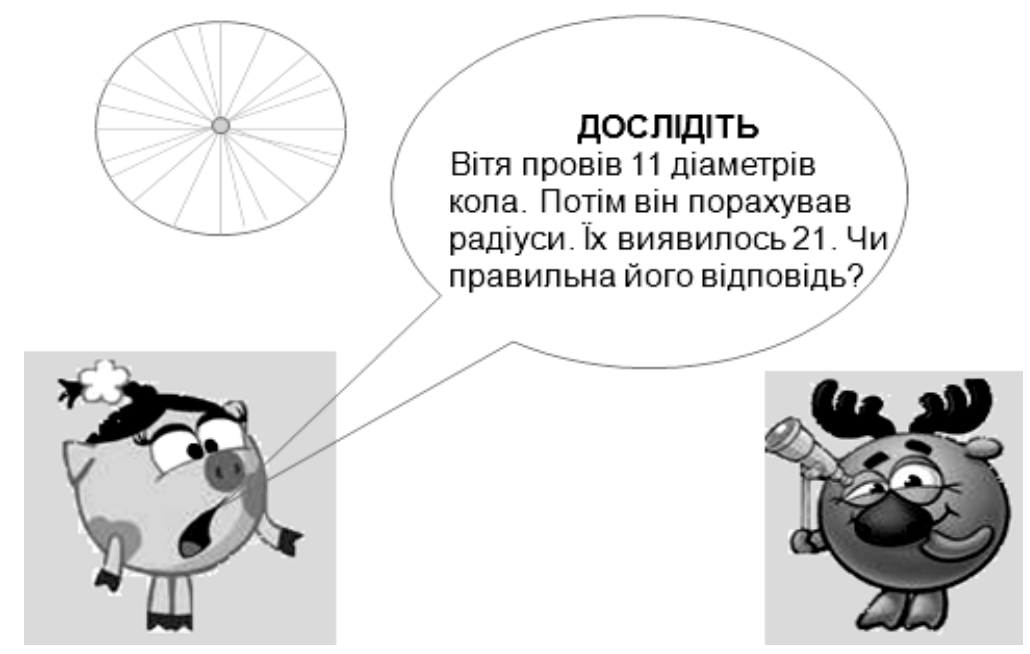

Рис. 3

Метод конструювання правил (теорій). Наприклад, застосування розподільного закону множення для швидких усних обчислень:

$$
\begin{aligned}
& a \cdot(в+c)=a \cdot b+a \cdot c \\
& 11 \cdot 73=(10+1) \cdot 73=730+73=803 \\
& 19 \cdot 32=(20-1) \cdot 32=640-32=608 \\
& 3 \frac{2}{5} \cdot 5=\left(3+\frac{2}{5}\right) \cdot 5=15+2=17
\end{aligned}
$$


Метод гіпотез. Наприклад, поділивши диню на дев'ять частин, учні порівнюють іiі частки (рис. 4) та формулюють гіпотезу про те, що з двох дробів з однаковими знаменниками більший той, у якого чисельник більший;

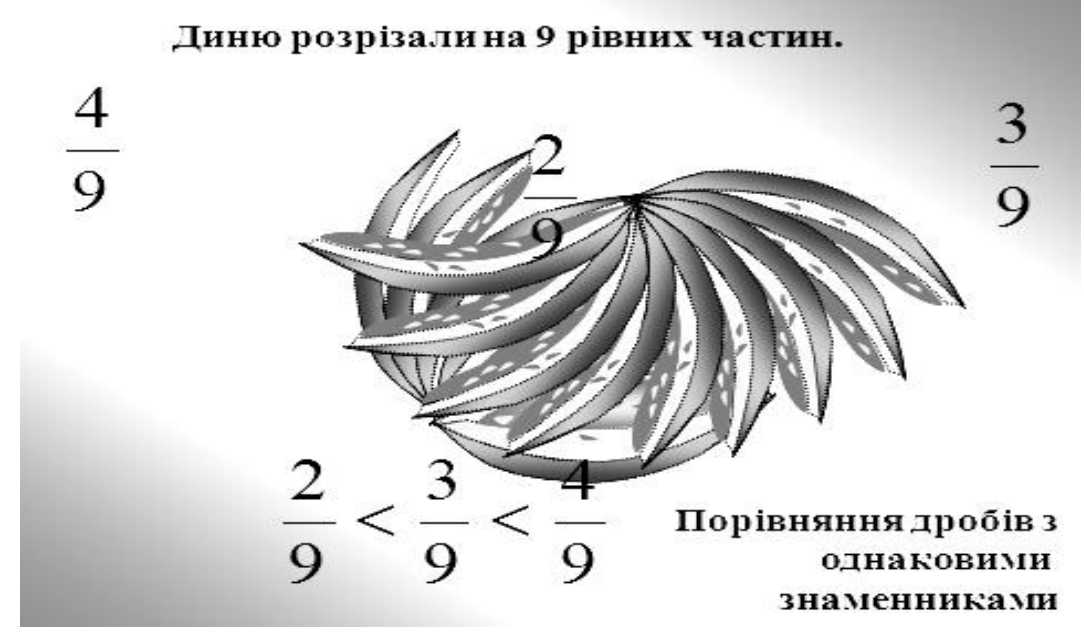

Рис. 4

Метод допоміжних задач дозволяє зробити процес розв'язання завдання керованим, заздалегідь передбачати труднощі учнів і допомогу в їх подоланні. Наприклад, розглядаючи старовинну задачу, учитель пропонує більш прості задачі, що будуть підводити до пошуку іiі розв'язування.

Задача. Летить зграя гусаків і на зустріч ій один гусак.

Добридень, сто гусей! - сказав ій гусак.

Нас не сто, - відповів ватажок зграї.

От якби нас було ще стільки, та півстільки, та чверть стільки, та ще один гусакось тоді б нас було сто гусей. Скільки гусей було у зграї?

Перш ніж розв'язувати подану задачу, розв'яжемо кілька простих завдань.

Задумали деяке число. Потім до нього додали це ж число і отримали 18. Яке число задумали?

Розв'язання: Нехай $x$ - задумане число. Тоді складемо рівняння: $x+x=18 \Rightarrow x=9$.

Відповідь: задумали число 9.

Задумали деяке число. Потім до нього додали половину ичього числа і отримали 36. Яке число задумали?

Розв'язання: Нехай $x$ - задумане число, тоді $\frac{1}{2} x$ - це половина задуманого числа. Складемо рівняння: $x+\frac{1}{2} x=36$, розв'язуючи дане рівняння учні знайдуть задумане число - 24.

Тепер 3 дітьми можна розв'язати старовинну задачу про гусей. Позначаючи за х кількість гусей у зграї, аналізуючи умову задачі і грунтуючись на попередніх завданнях, складемо рівняння для даної задачі:

$$
x+x+\frac{1}{2} x+\frac{1}{4} x+1=100 .
$$

Розв'язуючи рівняння, знаходимо відповідь - 36. Інтерпретуючи результат, отримуємо, що в зграї 36 гусей. 
Метод помилок. Він, наприклад, дозволяє проводити аналіз вивченого матеріалу, спостерігати, варіювати та робити аналогію між запропонованим неправильним розв'язанням завдання та своїм особистим (рис. 5).

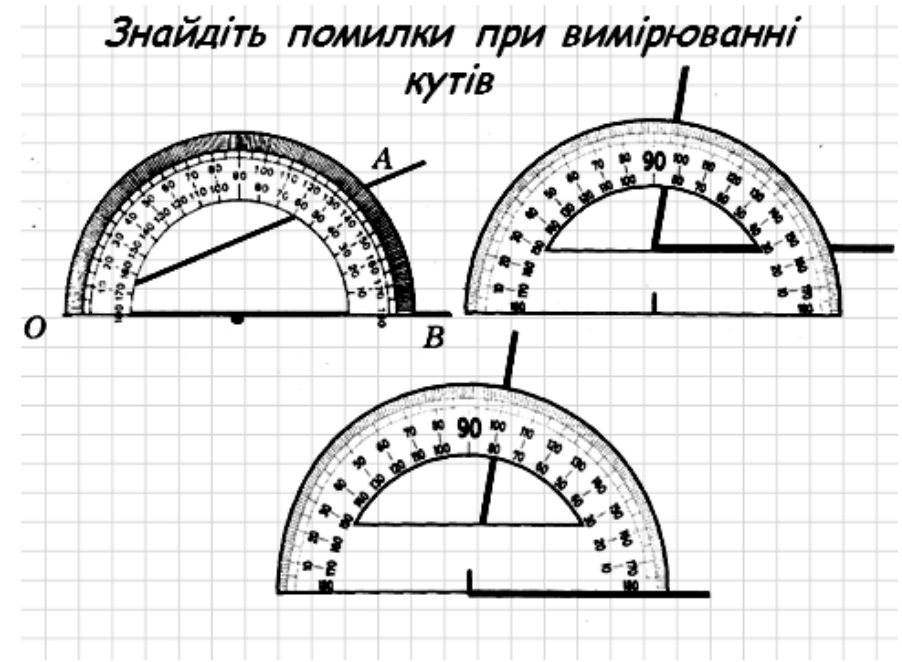

Рис. 5

Отже, ефективність роботи вчителя, рівень засвоєння навчального матеріалу та формування якостей особистості учня, зокрема вміння школярів викладати свої думки, обгрунтовувати і відстоювати свою думку, розвивати вміння аналізувати, порівнювати, узагальнювати, робити висновки, визначають методи навчання. У процесі навчання математики необхідно приділяти належну увагу методам навчання, в тому числі й евристичним. Тому подальшого розроблення потребують методи та прийоми формування евристичної діяльності учнів 5-6 класів з математики, наприклад, такі методи евристичного навчання математики, як: метод вигадування; метод проектів; метод рецензій; методи навчального цілепокладання; метод самоорганізації навчання та інші.

\section{Література}

1. Бабанский Ю. К. Педагогика : [учеб. пособие] / Ю. К. Бабанский. - $\quad$ М. : Просвещение, 1988. - 479 с. 2. Бевз Г. П. Методика викладання математики / Бевз Г. П. Київ : Вища школа, 1989. - 289 с. З. Васильсва Д. В. Методика навчання математики учнів 5-6 класів з використанням мультимедійної дошки : дис. на здобуття наук. ступеня канд. пед. наук: 13.00.02 / Д. В. Васильєва. - Київ, 2012. - 267 с. 4. Лернер И. Я. Дидактические основы методов обучения / $\quad$ И. Я. Лернер. - Москва : Педагогика, 1981. - 186 c. 5. Бурда М. І. Навчальна програма для учнів 5-9 класів загальноосвітніх навчальних закладів. Математика / М. І. Бурда, Ю.І.Мальований, Є. П. Нелін, Д. А. Номіровський, А. В. Паньков, Н. А. Тарасенкова, М. В. Чемерис, М. С. Якір. - Київ : Затверджено МОНМСУ, 2012. - 20 с. 6. Селевко Г. К. Проблемное обучение / Г. К. Селевко // Школьные технологии. $-\quad$ 2006. $-\quad$ № 2. $-\quad$ C. 61-65. 7. Скаткин М. Н. О методах обучения / М. Н. Скаткин, И. Я. Лернер // Советская педагогика. - 1965. - № 3. - С. 21-26. 8. Скафа О. І. Презентація як елемент комп'ютерно орієнтованого уроку математики / О. І. Скафа, О. В. Павліна // Математика в сучасній школі. - 2012. - № 5. - С. 35-39. 9. Столяр А. А. Педагогика математики : [курс лекций] / А. А. Столяр. - Минск : Вышэйшая школа, 1969. - 368 с. 10. Хуторской А. В. Развитие одаренности школьников : методика продуктивного обучения: [пособ. для учителя] / А. В. Хуторской. - Москва : Гуманитарный изд. центр «ВЛАДОС», 2000. - 320 с. 